\title{
Contribution to the knowledge of the parasitoid fauna of leaf mining sawflies (Hymenoptera: Tenthredinidae) of forest plants in Hungary
}

\author{
LEVENTE SZŐCS ${ }^{1}$ \\ MELIKA GEORGE ${ }^{2}$ \\ CSABA THURÓCZY3 \\ GYÖRGY CSÓKA ${ }^{1}$ \\ ${ }^{1}$ NARIC Forest Research Institute, Department \\ of Forest Protection, H-3232 Mátrafüred, Hungary \\ ${ }^{2}$ National Food Chain Safety Office, \\ Directorate of Plant Protection, Soil Conservation \\ and Agri-environment, Plant Health and Molecular \\ Biology Laboratory, H-1118 Budapest, Budaörsi str. \\ 141-14, Hungary \\ ${ }^{3}$ H-9730 Köszeg, Malomárok str. 27, Hungary \\ Correspondence \\ Levente Szőcs \\ E-mail:szocsl@erti.hu
}

Keywords: leaf mining sawfly, regulating potential, Braconidae, Eulophidae, Ichneumonidae
Received December 22, 2015

Revised January 14, 2016.

Accepted January 19, 2016.

\begin{abstract}
Background and Purpose: Despite the importance of studying the native enemy complex of the introduced and invasive leaf miner sawfly species in their native territories, few studies have been done in recent years concerning the species component and the regulating potential of their parasitoid complexes (in both native and invaded area). Heterarthrus vagans and Fenusa dohrnii are only some of the species which are native in Palearctic area, but alien invasive in North America, causing damage on forest plantations. In this short paper we provide our original data to the knowledge of parasitoid fauna associated with seven leaf mining sawflies native in Hungary.
\end{abstract}

Material and Methods: For a period of four years (2011-2014), several leaf miner species were collected and placed in single mine rearings. From the leafminers, belonging to the Tenthredinidae family, a total of 809 mines made by 9 different species (Heterarthrus wuestneii, Fenusa dohrnii, Heterarthrus vagans, Fenusa pumila, Fenusella nana, Profenusa pygmaea, Metallus pumilus, Parna apicalis, Fenusa ulmi) were collected from 19 locations across Hungary.

Results and Conclusions: A total of 188 specimens of 13 parasitoid species belonging to 3 families (Braconidae - 1; Ichneumonidae - 1 and Eulophidae - 11) were reared out from our samples. Parasitoid adults were obtained from 7 of the 9 species of leaf mining sawfly hosts (Fenusa dohrnii, Fenusa pumila, Fenusa ulmi, Heterarthrus vagans, Metallus pumilus, Parna apicalis, Profenusa pygmaea). From Heterarthrus wuestneii and Fenusella nana no parasitoid adults emerged.The parasitoid species presented in this work are typically associated with leaf mining sawflies. Several new host-parasitoid associations have been described.

\section{INTRODUCTION}

The Tenthredinidae family is the largest sawfly family, with at least 1 5,724 species worldwide (1). The family includes free feeding, gall inducing and leaf mining species (1-4). Leaf mining sawflies commonly make blotch mines on the upper side of the leaves, with irregularly deposited frass, less commonly bilateral (present on both sides) mines (5). Species pupating inside the mine, often make a disk-shaped cocoon chamber, like Heterarthrus vagans (Fallén, 1808). The leaf mining sawflies are regularly host specific (3). 
Some of our native leaf mining sawflies are alien and invasive in North America. H. vagans is bivoltine in Hungary (4) and it is native throughout the Palearctic region $(2,4)$. In 2009 it was found (as alien species) in the southwestern part of North America (6) on Alnus sp.. Fenusa dohrnii (Tischbein, 1846), which is also monophagus on alder (Alnus) species, often makes more than one mine on the upper side of the leaf (3). The larva pupates outside the mine. In North America (its non-native range), as an invasive pest, it causes serious problems in alder stands (7, 8). Fenusa pumila (Klug, 1816), and has also been found as an alien species in Alaska on Betula sp. (9). It has 2-3 generations per year both in its native range (3) and in the newly invaded territories where it can locally be abundant (9). Several blotch mines can be found on a single leaf between June and September (10). The species is oligophagous on hosts belonging to Betulaceae family.

Profenusa pygmaea (Klug, 1816) is univoltine and monophagous on Quercus species. Its mines can be found from May until the end of July $(3,11,12)$. It is common in its native range and can become really abundant in some locations (12).

On Ulmus species, Fenusa ulmi (Sundevall, 1847) is univoltine. The upper surface blotch mines can be found from May to June (4).
The blotch mines of Parna apicalis (Brischke, 1888) are located toward the margin of the leaf. The leafmier sawfly is monophagous on Tilia species (3).

Metallus pumilus (Klug, 1816) is oligophagous on Rubus species with two generations a year $(4,28)$. The importance of parasitoids as regulating factors of Lepidoptera species mining on trees (both native ones and aliens) is reflected in the high number of papers published in the past decade (13-19). Parasitoid complexes of leaf mining sawflies have been less studied recently, and only slightly some older publications deal with them (20-24) The Universal Chalcidoidae Database lists species associated with leaf mining sawflies only from a few works. In this short paper we provide our original data to the knowledge of parasitoid fauna associated with seven leaf mining sawflies native in Hungary.

\section{MATERIAL AND METHODS}

We studied the parasitoid complexes of various leaf mining sawflies during a four year period (2011-2014). A total of 809 mines made by 9 different species (all native in Hungary) were collected at 19 locations. The names and coordinates of the collecting locations are given in

Table 1: Collecting locations and their coordinates (decimal degrees) with the number of mines collected in different years

\begin{tabular}{|c|c|c|c|c|c|c|}
\hline Locations & Coordinates & 2011 & 2012 & 2013 & 2014 & Total \\
\hline Csörötnek & $46.936365,16.374056$ & & & 11 & & 11 \\
\hline Farkasgyepü & 47.199201, 17.637533 & & & 1 & & 1 \\
\hline Galyatető & $47.914998,19.928045$ & & & 6 & & 6 \\
\hline Gödöllő & $47.569384,19.381214$ & & & 5 & & 5 \\
\hline Gyöngyössolymos & $47.823067,19.926546$ & & 3 & 9 & 17 & 29 \\
\hline Királyrét & $47.894822 ; 18.974878$ & & & 1 & & 1 \\
\hline Kötegyán & $46.733336 ; 21.487859$ & 33 & & & & 33 \\
\hline Kunmadaras & $47.392356 ; 20.810463$ & & & 95 & & 95 \\
\hline Mátrafüred & $47.833894 ; 19.961676$ & 23 & 47 & 194 & 10 & 274 \\
\hline Mátraszőlős & $47.948090 ; 19.706682$ & & 9 & & & 9 \\
\hline Nadap & $47.259462 ; 18.606428$ & & & 26 & & 26 \\
\hline Pusztamiske & $47.066963 ; 17.442294$ & & & 97 & & 97 \\
\hline Püspökladány & $47.332753 ; 21.091173$ & & & 49 & & 49 \\
\hline Szarvas & $46.863383 ; 20.536829$ & & 13 & & & 13 \\
\hline Szeghalom & $47.011884 ; 21.136697$ & & 64 & & & 64 \\
\hline Tiszabura & $47.446905 ; 20.469560$ & 16 & & & & 16 \\
\hline Ugod & $47.304641 ; 17.618547$ & & & 7 & & 7 \\
\hline Várgesztes & $47.470887 ; 18.398589$ & & & 10 & & 10 \\
\hline Vértesacsa & $47.382252 ; 18.564229$ & & & 63 & & 63 \\
\hline Total: & & & & & & 809 \\
\hline
\end{tabular}


Table 2: Foodplants and voltinism of the hosts with the number of the mines collected

\begin{tabular}{|c|c|c|c|c|c|c|c|}
\hline Foodplant & Sawfly host & Voltinism & 2011 & 2012 & 2013 & 2014 & Total \\
\hline Acer campestre & Heterarthrus wuestneii & 1 & & 19 & 58 & & 77 \\
\hline \multirow[t]{2}{*}{ Alnus glutinosa } & Fenusa dohrnii & $2-3$ & & & 154 & 24 & 178 \\
\hline & Heterarthrus vagans & $2-3$ & & & 26 & & 26 \\
\hline \multirow[t]{3}{*}{ Betula pendula } & Fenusa pumila & $2-3$ & & & 39 & & 39 \\
\hline & Fenusa sp. & & & & 6 & & 6 \\
\hline & Fenusella nana & $1-2$ & & 3 & & & 3 \\
\hline Quercus spp. & Profenusa pygmaea & 1 & 23 & 36 & 139 & 3 & 191 \\
\hline Rubus spp. & Metallus pumilus & & 49 & & 11 & & 60 \\
\hline Tilia cordata & Parna apicalis & 1 & & 1 & 65 & & 66 \\
\hline Ulmus spp. & Fenusa ulmi & 1 & & 77 & 86 & & 163 \\
\hline Total: & & & 72 & 136 & 574 & 27 & 809 \\
\hline
\end{tabular}

Table 1, and the number of mines collected from different hostplants are found in Table 2.

The mines were carefully cut out from the leaf after the collection in order to avoid contamination by parasitoids attacking other insects on leaves (i.e. egg or aphid parasitoids). After a short period of drying, the samples were placed individually into air ventilated plastic rearing tubes. The parasitoids reared out were preserved in absolute ethanol and later identified by Csaba Thuróczy and George Melika. The emerging leaf miner adults were also identified to make sure that the identification of the leaf mines was correct. After the identification process, the adult insects were kept in ethanol in order to preserve them for future examinations (i.e. molecular analysis). The names of the hosts are from the Electronic World Catalogue of Symphita (1), while the names of the parasitoids follow Universal Chalcidoidae Database (25).

\section{RESULTS AND DISCUSSION}

From our samples, 188 adult parasitoid specimen emerged, belonging to 13 species of 3 families (1 Braco-

Table 3: The number of parasitoids reared from different hosts

\begin{tabular}{|c|c|c|c|c|c|c|c|c|c|}
\hline & & 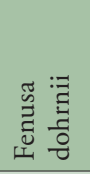 & 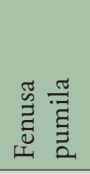 & 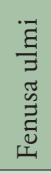 & 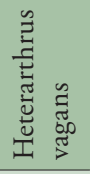 & 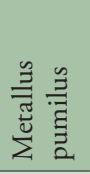 & 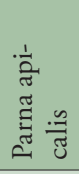 & 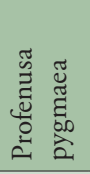 & 풍 \\
\hline Braconidae & Braconidae sp. & & & & & & & 1 & 1 \\
\hline Ichneumonidae & Itoplectis alternans & & & & & 2 & & & 2 \\
\hline \multirow[t]{11}{*}{ Eulophidae } & Achrysocharoides cilla & & & & & 7 & 1 & 5 & 13 \\
\hline & Aprostocetus sp. & & & 1 & & 1 & 1 & & 3 \\
\hline & Chrysocharis eurynota & & & & & & & 35 & 35 \\
\hline & Chrysocharis nitetis & & & & & & & 61 & 61 \\
\hline & Chrysocharis pentheus & 4 & 2 & 1 & & & & 1 & 8 \\
\hline & Chrysocharis sp. & & & & & & & 7 & 7 \\
\hline & Chrysocharis sp. $B-c f$. nitidifrons & & & & 40 & & & & 40 \\
\hline & Closterocerus trifasciatus & & & & & & & 1 & 1 \\
\hline & Minotetrastichus frontalis & & & & & & & 1 & 1 \\
\hline & Pnigalio pectinicornis & 4 & & & & 9 & & 1 & 14 \\
\hline & Sympiesis sericeicornis & 1 & & & & 1 & & & 2 \\
\hline Total: & & 9 & 2 & 2 & 40 & 20 & 2 & 113 & 188 \\
\hline
\end{tabular}


nidae; 11 Eulophidae and 1 Ichneumonidae) (Table 3). No parasitoids emerged from mines of the Heterarthrus wuestneii (Konov, 1905) and Fenusella nana (Klug, 1816). The parasitism rate varied from $1.5 \%$ to $19 \%$ among localities and host species.

A total of 9 parasitoid species, belonging to 2 families (Braconidae and Eulophidae) have been identified from P. pygmaea. The parasitism rates varied between $12 \%$ ( $\mathrm{n}=67$ leaf mines) and 15\% ( $\mathrm{n}=94$ leaf mines). The dominant parasitoid species were the Chrysocharis nitetis (Walker, 1839) and Chrysocharis eurynota (Graham, 1963). These species showed gregarious character (more than one parasitoid developing on a single host). Five specimens of Achrysocharoides cilla (Walker, 1839) (koinobiont endoparasitoid) were found at only one location (Mátrafüred). The parasitoid complex of $P$. pygmaea seems to be composed of typical sawfly parasitoids (20, $22,23,25,26)$.

Only one parasitoid species, Chrysocharis sp. B -cf nitidifrons (Graham, 1963) ( $\mathrm{n}=26$ leaf mines) was reared out from $H$. vagans mines. The "cf. nitidifrons" means that the specimens identified were close to $C$. nitidifrons, but due to some special signs we could not be $100 \%$ confident in the determination. C. nitidifrons has very few known host associates, which are the following: Cimbex quadrimaculata (Müller, 1766), Ectoedemia argyropeza (Zeller, 1839), Stigmella splendidissimella (Herrich-Schäffer, 1855) and Emmetia angusticolella (Duponchel, 1843), Emmetia marginea (Harworth,1828) $(26,27)$. According to Noyes (2015) (25), this parasitoid is oligophagous on Crataegus bus sp. These host plants are a well-known component of mixed broadleaved forests. The Global Chalcidoidae Database lists eight species of parasitoids for $H$. vagans, none of which were reared during this research. The $C$. sp. B -cf nitidifrons was not listed neither by Noyes (2015) (25) nor by Schönrogge (21) as a parasitoid of $H$. vagans.

From Fenusa dohrnii, three species, Chrysocharis pentheus (Walker, 1839), Pnigalio pectinicornis (Linnaeus, 1758) and Sympiesis sericeicornis (Nees, 1834) have been reared and identified. For the samples collected in Mátrafüred, the parasitation rate was 3.1\% ( $\mathrm{n}=64$ leaf mines), and for the samples of Pusztamiske, was $7.2 \%$ ( $\mathrm{n}=92$ leaf mines). The samples from other locations produced no parasitoids. Six species were listed by the Universal Chalcidoidae Database (Noyes 2015) as parasitoid associates of $F$. dohrnii. Despite both $C$. pentheus and $S$. sericeicornis being considered generalits, none of them have been recorded on $F$. dohrnii so far $(23,25)$.

Of the leaf miner sawflies mining on Betula, only the samples of $F$. pumila and F. ulmi contained parasitoids. $C$. pentheus was reared out from both of the leaf miners while Aprostocetus sp. only from F. ulmi.
The parasitoid complex of the Metallus pumilus was dominated by two generalist species, $A$. cilla and $P$. pectinicornis (28).

Only two parasitoid species (A. cilla and Aprostocetus sp.) were reared out from mines of Parna apicalis collected from Tilia cordata.

Overall, the parasitoid species, listed in this work, are typical parasitoids of leaf mining sawflies. Eight of them are largely polyphagous and can be found on leaf mining lepidoptera $(20,22,23,28,29)$, as well as on invasive species $(14,19)$. Specialist parasitoids of leaf mining sawflies, species like $C$. nitetis, $C$. eurynota and $C$. sp. B - cf nitidifrons were also reared out and identified.

The natural enemy complex of a leaf miner is composed mainly from parasitoid wasp species (Hymenoptera) (30-32) but in almost all instances a preference for a particular type of host is evident. The parasitoid faunas of tree leaf-mining Lepidoptera, Coleoptera and Hymenoptera are shown to be qualitatively similar, but those of Diptera are rather different. The parasite faunas of tree leaf-miners are different also from those of leaf gall-forming insects on trees and, to a lesser degree, from those of leaf-miners on herbaceous plants. The parasite fauna associated with a tree genus is quantitatively and qualitatively characteristic and, in general, it most resembles that found on allied tree genera. Congeneric leapminers attacking the same tree species are attacked by very similar parasite faunas, although mine situation and season of development may exert some influence. These latter factors are considered especially in relation to leaf-miners of the genus Phyllonorycter for which most data are available. The parasitoid complex of the alien leaf miner species will be composed from the native parasitoid assemblages of the invaded area $(14,19,33)$. Cameraria ohridella (Deschka \& Dimic, 1986), was discovered during a mass outbreak on planted horse-chestnut trees, Aesculus hippocastanum, near Lake Ohrid in Macedonia. However, several peculiarities in the leafminer's biology and ecology, such as its inefficient control through natural enemies, indicate that it may be of exotic origin. In this study, the parasitism of C. obridella was examined in natural and artificial horse-chestnut stands in South-eastern Europe. The size and composition of the parasitoid complex of natural stands was comparable with that known from artificial stands. No specialist parasitoid species were detected in any of the samples. The only parasitoid species found exclusively in natural stands during this investigation were the braconid Colastes braconius (Haliday, 1983) and the eulophid Chrysocharis phryne (Walker, 1839). Both are known to be polyphagous on many leafminers in Europe and C. braconius has been often recorded from C. ohridella in artificial stands in previous studies. Parasitism levels varied within the same range $(3.6-21.0 \%$. Thus at the beginning of the invasion, the native enemy complex is unable to regulate the new species $(15,34,35)$. 
Studying the parasitoid complexes of the leaf mining sawflies in their native range can be important, particularly because they are potential alien invasive pests in other continents/countries (ex.: Heterarthrus vagans and Profenusa thomsoni) or species with an outbreak potential in their native range (Profenusa pygmaea). Considering the small sample sizes and the small amount of identified parasitoids, further rearings (with larger samples from more geographic locations) will help to provide a wider knowledge of the leaf miner sawfly parasitoid fauna and its influence on host species.

Acknowledgments. This study was supported by the Agrárklima.2 VKSZ_12-1-2013-0034 project sponsored by the Hungarian State and the National Research, Development and Innovation Fund.

\section{REFERENCES}

1. TAEGER A, BLANK S, LISTON A 2010 World Catalogue of Symphyta (Hymenoptera). Zootaxa 1064(2580):1-1064

2. ZOMBORI L 1982 Levéldarázs-alkatúak II. - Tenthredinoidea II., Vol. 11 Budapest: Akadémia kiadó

3. ZOMBORI L 1990 Levéldarázs-alkatúak III. - Tenthredinoidea III., Vol. 165 Budapest: Akadémia kiadó

4. CSÓKA G 2003 Levélaknák és levélaknázók - Leaf mines and leaf miners Budapest: Agroinform Kiadó és Nyomda. 192 pp.

5. ALTENHOFER E, PSCHORN-WALCHER H 2003 Biologische notizen über die blattwespen-gattungen Metallus Forbes, Monostegia a. Costa und Phymatocera dablbom (Hymenoptera: Tenthredinidae). Linzer Biologioshe Beitrage 35(1):405-17

6. HUMBLE L 2012 First North American records for Heterarthrus vagans (Hymenoptera: Tenthredinidae), a palaearctic leafmining sawfly of alder. The Canadian Entomologist 142(02):181-87 http:// dx.doi.org/10.4039/n09-071

7. HART E, HALL B, HANNA R 1991 Dispersal of Fenusa dohrnii (Fymenoptera: tenthredinidae) from an alnus short-rotation forest plantation. Great Lakes Entomologist 24(2):63-68

8. DIGWEED S, LANGOR D 2004 Distributions of leafmining sawflies (Hymenoptera: Tenthredinidae) on birch and alder in Northwestern Canada. The Canadian Entomologist 136:727-31 http://dx.doi.org/10.4039/n03-096

9. SNYDER C, MACQUARRIE CJK, ZOGAS K, KRUSE JJ, HARD J 2007 Invasive species in the last frontier: distribution and phenology of birch leaf mining sawflies in Alaska. Journal of Forestry 105(May):113-19

10. LINDQUIST O $1959 \mathrm{~A}$ key to the larvae of leaf-mining sawflies on birch in Ontario with notes on their biology. The Canadian Entomologist 91(509):625-27 http://dx.doi.org/10.4039/Ent91625-10

11. MATOSEVIC D, PERNEK M, DUBRAVAC T, BARIC B 2009 Research of leafminers on woody plants in Croatia. Sumarski list 453:381-90

12. TUBA K, TÓTH V, OROZUMBEKOV A, LAKATOS F 2012 Profenusa pygmaea (Klug 1816): a duble-faced sawfly. Joint IUFRO 7.03.10 - "Methodology of forest insect and disease survey" and IUFRO WP 7.03.06 - "Integrated management of forest defoliating insects". Palanga, Lithuania., pp. 14-15

13. MATOSEVIC D, MELIKA G 2013: Recruitment of native parasitoids to a new invasive host: first results of Dryocosmus kuriphilus parasitoid assemblage in Croatia. Bulletin of Insectology 66(2):23138
14. CSÓKA G, PÉNZES Z, HIRKA A, MIKÓ I, MATOSEVIC D, MELIKA G 2009 Parasitoid assemblages of two invading black locust leaf miners, Phyllonorycter robiniella and Parectopa robiniella in Hungary. Periodicum Biologorum 111(4):405-11

15. MATOSEVIC D, MELIKA G 2012 Diversity of parasitoid assemblages of native and alien leaf miners in Croatia. Sumarski List 442:367-76

16. LUPI D 2005 A 3 year field survey of the natural enemies of the horse-chestnut leaf miner Cameraria ohridella in Lombardy, Italy. BioControl 50(1):113-26 http://dx.doi.org/10.1007/s10526-0040298-2

17. GRABENWEGER G, KEHRLI P, STEINER F, STOLZ M, BACHER S 2005 Predator complex of the horse chestnut leafminer Cameraria obridella: identification and impact assessment. JEN $129(7)$

18. ERMOLAEV IV, YEFREMOVA ZA, IZHBOLDINA NV 2011 Parasitoids as a mortality factor for the lime leafminer (Phyllonorycter issikii, Lepidoptera, Gracillariidae). Entomological Review 91(3):326-34 http://dx.doi.org/10.1134/S0013873811030067

19. SZŐCS L, MELIKA G, THURÓCZY C, CSÓKA G 2015 Parasitoids of the lime leaf miner Phyllonorycter issikii (Lepidoptera: Gracillariide) recorded throughout the area it recently colonized. European Journal of Entomology 112(4):1-8 http://dx.doi.org/10.14411/eje.2015.101

20. SCHÖNROGGE K, ALTENHOFER E 1992 On the biology and larval parasitoids of the leaf-mining sawflies Profenusa thomsoni (Konow) and P. pygmaea (Konow) (Hym., Tenthredinidae). Entomologists Monthly Magazine 128:99-108

21. DOWDEN P 1941 Parasites of the birch leaf-mining sawfly (Phyllotoma nemorata). USDA Technical Bulletin, pp. 1-56

22. ASKEW R, COSHAN P 1973 A study of Chrysocharis nephereus (Walker) (Hymenoptera: Eulophidae) and allied species, with observations on their biology in Northern England. Journal of Natural History 7(1):47-63 http://dx.doi.org/10.1080/00222937300770041

23. ALTENHOFER E 1980 Zur systematik und ökologie der larvenparasiten (Hym., Ichneumonidae, Braconidae, Eulophidae) der rninierenden blattwespen (Hym., Tenthredinidae). Zeitschrift fürAngewandte Entomologie. 89:250-59

24. LAGNOR D, DIGWEED S, WILLIAMS M, SPENCE J, SAUNDERS C 2000 Establishment and spread of two parasitoids (Ichneumonidae) of the birch leafminer, Fenusa pusilla (Tenthredinidae). Biocontrol 45:415-23 http://dx.doi.org/10.1023/A:1026598305752

25. NOYES JS 2015 Universal Chalcidoidea Database. World Wide Web electronic publication.

http://www.nhm.ac.uk/research-curation/research/projects/chalcidoids/database/

26. ASKEW R 1984 Species of pnigalio and Chrysocharis (Hymenoptera: Eulophidae) parasitic in Tischeriidae (Lepidoptera) with the description of a new species. Entomologist's Gazette 35:103-9

27. HANSSON C 1985 Taxonomy and biology of the palaearctic species of Chrysocharis Förster, 1856 (Hymenoptera: Eulophidae). Scandinavian Entomology Supplement, p. 76

28. SZÖCS L, MELIKA G, THURÓCZY C, CSÓKA G 2014 Data on the parasitoid complexes of Metallus pumilus (Hymenoptera: Tenthredinidae) and Emmetia heinemanni (Lepidoptera: Tischeriidae) mining leaves on Rubus sp. Folia Entomologica Hungarica 75:167-71 http://dx.doi.org/10.17112/FoliaEntHung.2014.75.167

29. SZÖCS L, MELIKA G, CSÓKA G 2013 Adatok a hazai tölgyeken előforduló levélaknázók parazitoid együtteseinek ismeretéhez. Erdészettudományi Közlemények 3(1):251-59

30. ASKEW R, SHAW M 1974 An account of the Chalcidoidea (Hymenoptera) parasitising leaf-mining insects of deciduous trees in Britain. Biological Journal of the Linnean Society 6(December):289-335 http://dx.doi.org/10.1111/j.1095-8312.1974.tb00727.x 
31. GODFRAY HCJ 1994 Parasitoids: behavioral and evolutionary ecology Princeton, N.J.: Princeton University Press.

32. HAWKINS BA, CORNELL HW, HOCHBERG ME 1997 Predators, parasitoids and pathohens as mortality agents in phytophagous insect populations. Ecology 78(7):2145-52

http://dx.doi.org/10.1890/0012-9658(1997)078[2145:PPAPAM]2. $0 . \mathrm{CO} ; 2$

33. GRABENWEGER G, AVTZIS N, GIRARDOZ S, HRASOVEC B, TOMOV R, KENIS M 2005 Parasitism of Cameraria ohridella (Lepidoptera, Gracillariidae) in natural and artificial horse-chestnut stands in the Balkans. Agricultural and Forest Entomology 7(4):291$96 \mathrm{http}: / / \mathrm{dx}$.doi.org/10.1111/j.1461-9555.2005.00269.x

34. VOLTER L, KENIS M 2006 Parasitoid complex and parasitism rates of the horse chestnut leafminer, Cameraria ohridella (Lepidoptera: Gracillariidae) in the Czech Republic, Slovakia and Slovenia. European Journal of Entomology 103:365-70

http://dx.doi.org/10.14411/eje.2006.049

35. SZŐCS L, MELIKA G, THURÓCZY C, CSÓKA G 2014 Adatok az invázív hárslevél sátorosmoly (Phyllonorycter issikii Kumata, 1963) Magyarországi parazitoid együtteseinek ismeretéhez. Növényvédelem 50(10):445-51 